\title{
Ibn 'Arabi and the Ambiguous Verses of the Quran: Beyond the Letter and Pure Reason
}

\author{
Syamsuddin Arif \\ Universitas Darus Salam Gontor \\ email: tagesauge@gmail.com
}

\begin{abstract}
Abstrak
This article attempts to clarify this issue and explain Ibn 'Arabi's interpretive method, particularly in dealing with the so-called 'ambiguous verses' (ayat mutashabihat) of the Holy Quran, on the basis of meticulous reading of several relevant chapters of his kitab al-Futuhat al-Makkiyyah ('Meccan Illuminations') and other treatises. The discussion reveals Ibn 'Arabi's approach to Quranic interpretation which rests on the assumption that all the possible meanings that the Arabic language allows for any given word or group of words in the Quran are valid, and that rejection of any one of these meanings would imply limiting God's knowledge and inappropriately saying that God was unaware of the various ways in which His Word could be interpreted. In contrast to the theologians (Mutakallimun) and philosophers (Falasifah), Ibn 'Arabi rejects rational interpretation (ta'wil 'aqli) outright. If reason finds the ambiguous verses of the Quran unacceptable, this only proves its own imperfection and failure to comprehend, not the necessity of interpretation. While he insists that one's reading of the Quran must conform to the Arabic language as spoken by its original recipient, Ibn 'Arabi more often than not offers surprising and highly original interpretations that seek to unveil the mystical treasures hidden in the text.
\end{abstract}

\section{Kata kunci:}

Ibn 'Arabi; esoteric interpretation; scriptural hermeneutics; Ambiguous Verses (Ayat Mutashabihat) 


\section{Introduction}

Of many prominent Sufis, few thinkers have attracted so considerable attention and evoked as much mixed reactions as did Ibn 'Arabi (d. 638/1240), often called al-Shaykh al-Akbar ('Grand Master'), whose complete name is Muhammad ibn 'Ali ibn Muhammad al-Ta'i alHatimi. A prolific scholar, Ibn 'Arabi has written over three hundred highly influential and technical treatises, including the encyclopedic al-Futubat alMakkiyyah ('The Meccan Illuminations') and the controversial Fusus alHikam ('The Bezels of Wisdom') as well as a fine collections of poetry, all of which are at the same time intensely innovative and deeply rooted in the Holy Quran and canonical traditions (badith) of the Prophet, creating a synthesis of earlier intellectual and spiritual traditions, and integrating the perspectives of jurisprudence (figh), philosophy (falsafah), theology (kalam), and Sufism (Yahla 1964); (Elmore 2004: 360-380).

Despite abundant references to the Quran and Prophetic traditions (badith), Ibn 'Arabi's writings especially the Fusus have aroused the interest and ire of a great number of scholars and generated a string of commentaries, critiques and apologies (Knysh 1999a); (Chodkiewics 1999: 93-123). To him is ascribed the 'unorthodox' view about Quran that its verses are considered to have an interior, symbolic meaning that requires a transrational interpretation and an unusual hermeneutical approach. Ibn 'Arabi is often said to have given preference to the esoteric sense over the literal meaning of the Quran (Al-Dhahabi 1961: 407-416). Not surprisingly then, detractors charged him with disbelief, accusing him of having twisted the meaning of sacred text in support of his allegedly heretic views. While not entirely false, this widespread claim, which persists to this day both in the West and the Muslim world, (Goldziher 1970: 180-262); (Al-Najjar 1965); (Zayd 1983: 177-180) needs to be reassessed because Ibn 'Arabi does in fact rebuke both those who are obsessed with the hidden meaning aswell as those who content them selves with the literal meaning 
alone (Chodkiewics 1992); (Streight 1993); (Chittick 1989). This article attempts to clarify this issue and explain Ibn 'Arabi's interpretive method, particularly in dealing with the theologically problematic, ambiguous verses (ayat mutashabihat) of the Holy Quran, on the basis of meticulous reading of several relevant chapters of his kitab al-Futuhat al-Makkizyyah ('Meccan Illuminations') and other treatises.

Ibn 'Arabi was born in 1165 to a family of high standing in Murcia, Spain, where his father was a government official, and later moved to Seville, where he grew up and received his early education. Since childhood he had been strongly attracted to mysticism. This interest led him to a serious study of Sufi doctrines and to repeated sojourns in his homeland and in North Africa to learn from their saints and scholars such as Ibn Bashkuwal, Abu Madyan and Ibn Rushd. He reportedly had a series of visionary experience in which he claims to have been initiated into the path directly by the prophets, from Jesus through Khidr to Muhammad -peace be upon him. It was in such a vision, in 1200, that he was ordered to go to the East, where he spent the rest of his life. After making the pilgrimage to Mecca, he wandered between Cairo, Konya and Baghdad, being honored by various local Seljuq and Ayyubid rulers and attracting a growing number of disciples, before he finally settled, in 1223, in Damascus, where he continued to teach and write until his death in 1240 (Al-Dhahabi 2001, 23: 48-49); (Al-Yafi'i 1970, 4: 100-101); (Al-Ghubrini 1979: 156-173); (Al-Sha'rani 1888, 1: 187-188); (Addas 1989); (Addas 1993); (Corbin 1969: 38-73); (Nasr 1975: 92-97); (Knysh 1999b: 25-47).

Unlike his fellow countrymen Abu Hayyan al-Andalusi or al-Qurtubi who are well-known for their voluminous tafsir works, Ibn 'Arabi did not write a commentary on the Quran as such but found many occasions on which to record his approach to the sacred text from his own point of view. In his major works Ibn 'Arabi typically begins any discussion with a verse or two, and then he proceeds to extract meanings that have 
a bearing on whatever the context may be. There is indeed a tafsir book attributed to him under the title Tafsir al-Quran al-Karim. Published in Beirut by Dar al-Yaqzah al-'Arabiyyah in 1968, the two-volume work is believed to be composed by 'Abd al-Razzaq al-Qashani (d. 730/1329), a famous commentator of the Fusus who drew upon Ibn 'Arabi's language, concepts, and tendencies in a creative fashion to craft his own system of mystical-philosophical theology. The editor of the work, Mustafa Ghalib, claims that Ibn 'Arabi produced three tafsir, namely: (1) al-Jam'u wa-l Tafsil fi Asrar Ma'ani al-Tanzil ('The Collection and Detailed Exposition of the Secret Meanings of the Revelation'), (2) al-Babru al-Masjur fi Tafsir al-Quran bi Mabd al-Nur ('The Swell-full Ocean on the Interpretation with Pure Light'), and (3) I'jaz al-Bayan fi Tafsir al-Quran ('Concise Explanation on the Exegesis of the Quran'), of which only the last two are extant. Yet, most scholars are agreed that Ibn 'Arabi never actually compiled a tafsir work of his own.

\section{Tafsir and Ta'wil}

Ibn 'Arabi regarded the Quran as a source of divine secrets that can be unlocked by the faithful to whom it is addressed. Muslim scholars refer to this activity of deciphering God's Speech as tafsir and ta'wil. ${ }^{1}$ Although for a time considered synonymous, these two words have acquired different meanings as the Quranic sciences developed in the early centuries of Islam. While tafsir remained the term of more limited denotation, being restricted to traditional interpretation or philological exegesis, ta'wil has been used to signify hermeneutical approaches that sought to uncover deeper meanings in the text or to align the text with particular theological, philosophical or mystical ideas. More substantial distinction has been drawn by later scholars who take ta'wil to include all kinds of allegorical

1 In this article I use the word 'exegesis' in the sense of textual commentary (tafsir), in contrast to 'allegorical interpretation' (ta'wīl).

DINIKA, Volume 4, Number 2, May - August 2019 
interpretation based on reason (bi al-dirayah) in order to excavate every possible meaning the text may bear and to determine the best one without making any truth claim (tarjibahad mubtamalat al-lafz bi dun al-qat ${ }^{\dagger}$ ), reserving tafsir for textual elucidation based solely on the true reports transmitted by trustworthy authorities from reliable eye-witnesses of the Revelation (bi '-riwayah) (Al-Maturidi 1983: 5-6). Accordingly, nobody is allowed to comment on any verse of the Quran since the right to make tafsir belongs exclusively to the Prophet and his Companions, whereas ta'wil is permitted so long as (1) it does not claim to represent the true meaning intended by God and (2) provided it does not contradict other relevant verses of the Quran or traditions of the Prophet (Al-Zarkashi 1957, 2: 148-150); (Al-Suyuti 1978, 2:221). No wonder then, tafsir, being understood as the collection and evaluation of relevant explanatory hadiths -hence the redundant designation al-tafsir bi al-ma'thur-, is set in binary opposition to the commonly disparaged 'subjective interpretation' (tafsir bi al-ra'yz) associated with ta'wil.

In Ibn 'Arabi's writings, the term ta'wil and its derivatives are used almost invariably to refer to allegorical interpretation based on rational consideration (nadzar) and thinking (fikr) whereby every verse which are considered contradictory to the traditional doctrines of God's incomparability is explained away ('Arabi, n.d.: 218, 523). He also means by ta'wil the taking of one's rational understanding of God as the scale (mizan) ('Arabi, n.d., 2: 645) or standard by which to weigh the revelation. That is to say, according to the proponents of ta'wil, everything which corresponds to rational understanding is accepted, while everything else that does not should be interpreted or ta'wilized to bring it into line with that rational understanding, such that man becomes the standard for judging the revelation, and the Quran is no longer the standard for judging man $-\mathrm{a}$ view that is reminiscent of Protagoras' doctrine: bomo mensuraomniumrerumest ('man is the measure of all things'). 
Ibn 'Arabi rejects the rationalistic approach categorically, insisting instead that man must allow himself to be judged, shaped, and transformed by the Speech of God (Kalam Allah); man must devote himself to worship (ibadah) and God-fearing (taqwa), to recitation of the Quran, and to all the spiritual disciplines set down by the Shari'ah ('Arabi, n.d., 2: 167-168). When it comes to understanding the Revelation, man must constantly pray to God to enlighten him as to the meaning of Divine Word and to increase him in knowledge. Even if God has unveiled to him the meaning of a verse or a portion of the Quran, man still must weigh what he receives through unveiling (kashff) in the scales of the Shari'ah and the Sunnah, lest it be a mere deceit (talbis) or self-deception in the guise of divine form (makr nafsiyy bi surab ilahiyyah) ('Arabi, n.d., 2: 223). Only when such spiritual vision conforms to the Quran and Sunnah can it be taken seriously.

Given the fact that Ibn 'Arabi rejects the Mutakallimun's and the Falasifah' rational procedures in interpreting the obscure verses, it is unjust therefore to describe his approach and commentary as ta'wil, contrary to the opinion of Henri Corbin and Nasr Hamid Abu Zayd (Henry Corbin 1969); (Zayd 1983). As we all know, there exist a number of Quranic verses and Prophetic Hadiths which speak of God's hand (yadullab), God's finger (asbu' al-rahman), God's eyes (bi-a'yunina), God's face (wajbullab) and God being seated on theThrone ('ala al-arshistawa), coming down to the lower heaven (yanzil ila al-sama' al-dunya) and directly speaking to Moses. Since to understand these verses literally would smack of anthropomorphism (tajsim) and comparison (tashbib), many theologians and philosophers choose to interpret them allegorically, even though it would mean a departure from, or repudiation of the text. Ibn 'Arabi criticizes both approaches, condemning the purely literal, anthropomorphic understanding while at the same time rejecting every ta'wil that seeks to interpret those ambiguous or seemingly paradoxical verses in a way that will neither compromise nor contradict the principles of rational thought. 
This perennial debate which has divided scholars into the pro-ta'wil and anti-ta'wil camps, springs from the famous passage in the Quran (3:7) about the verses being either "clear" or "ambiguous":

It is He who sent down upon you the Book; in it are clear verses (ayat mubkamat) which are the mother of the Book, and others are ambiguous (mutashabihat). Those in whose hearts is perversity, they follow the ambiguous part thereof, pursuing trouble, and searching for its interpretation; but nobody knows its interpretation except God [;] and those who are firmly rooted in knowledge; they say, "We have faith in it; all comes from our Lord."2

Scholars disagree over which verses are clear and which are obscure and the debate ensues over the punctuation of the verse. Those who maintain that the true meaning of ambiguous verses is known only to God will read the verse with a full stop separating the sentence wa ma ya'lamu ta'wilahu illa Allah and the phrase wa al-rasikhun fi al-ilm-a view subscribed by the majority and most of the Hanafites (Al-Alusi 1985, 3: 84). Another possible reading takes the particle waw as a conjunctive (adat al-'atf) rather than a concessive particle (barf al-istinaff), thereby ascribing the capacity of understanding and the right of interpreting the ambiguous verses not merely to God but also to "those firmly rooted in knowledge." Ibn 'Arabi, like most of the Shafi'ites, accepts the second reading, though on a slightly different ground and without ignoring the implications of the sentence "We have faith in it; all comes from our Lord (amanna bibi, kullun min 'indi Rabbina)" These are, Ibn 'Arabi tells us, the people whom God has taught everything which the written, revealed word is referring to (maya'ul ilayh al-lafy), namely the meanings He had deposited within it, which they know without reflection (min ghayr fikr) since in itself thinking is not immune to error -afact true for everyone without exception ('Arabi, n.d., 2: 594).

2 Translation of verses and passages herein quoted is mine unless otherwise specified. 
Among those who see the need for ta'wil, al-Ghazali seems to represent the theologians (Mutakallimun) when he states that "concerning anything which reason judges to be impossible, it is incumbent to interpret allegorically what the revelation says about it; for it is inconceivable that the revelation contains a decisive text that is contradictory to reason." (AlGhazali 1962: 212). But in such interpretation, Ibn 'Arabi would contend, instead of having faith in literal accuracy of the revelation and trying to understand it in God's terms, the interpreter accepts the supremacy of his own reason and its ability to judge all things. In effect, reason becomes the scale in which everything must be weighed including God's Speech. Ibn 'Arabi clarifies his position in the following passage:

You say concerning God that $\mathrm{He}$ is hearing and seeing. He has a hand, two hands, hands, eyes, leg, and everything $\mathrm{He}$ has ascribed to Himself, which our reason cannot accept, since those can only be ascribed to created things. Were it not for what has been brought by the Shari'ah and the divine Prophetic reports, we could not ascribe these things to Him rationally. However, we refuse to declare any similarity and do not discuss anything specific, since we are ignorant of His essence (lijablina bi dhatibi). We deny similarity simply because of His statement, "Nothing is like Him" (42:11), not because of our rational judgement, so that nothing judges Him except His own speech ('Arabi, n.d., 2: 291).

When he criticizes allegorical interpretation based on reason, Ibn 'Arabi has in mind 'reason' ('aql) used by theologians and philosophers who insist on interpreting the revealed texts in agreement with their own presuppositions and rational criteria (istanfa arkana dalilibi) ('Arabi, n.d., 2: 645). It is something which the Prophet refers to in one hadith: "Whosoever interprets or comments on the Quran on the basis of his personal opinion (fassara al-Qurana bi ra'jibi) will surely occupy his seat in the Hell-fire."’3 As other hadiths indicate, this prophetic denunciation

3 Reported by al-Tirmidh̄̄, AbīDawūd, and al-Nasa'̄ from Ibn 'Abbas.

DINIKA, Volume 4, Number 2, May - August 2019 
extends even to those instances where rational or allegorical interpretation may perhaps be correct. For the stress here is on venturing into such matters inadequately prepared. According to Ibn 'Arabi, one should have faith (iman) in the Quran's clear and ambiguous verses, and must simply accept everything brought by the Prophet as they are. For in his view, the person who interprets the revealed texts allegorically in fact has faith only in his own ta'wil and reason, but has lost faith in the Revelation. We read in the Futubat.

"...[God] who commands us to have faith in its [i.e. the Quran's] clear and ambiguous verses and to accept everything the Prophet has brought, because if we interpret (ta'awnalna) any of it, saying, "In fact, this is what the Speaker means by His words," then the degree of faith will disappear from us. For, in that case, the rational argument determines [the truth of] the report, thereby undermining the judgement of faith. But true understanding actually comes from the person of faith, who will say to such a man of rational proof: "The judgement given by your rational consideration ( hadha al-qat" alladhi a'taka nadzaruka) concerning the intention of God in His speech is but ignorance an sich and only shows your lack of true knowledge. For, even if it happens to concur with knowledge, your faith has already gone (zala 'anka al-iman)" ('Arabi, n.d., 2: 660).

On Ibn 'Arabi's account, one should never doubt the accuracy of the revealed text in its literal form. To suggest that God's real meaning lies below the surface or has to be found through allegorical interpretation using rational scales is to cast aspersions upon God and only shows lack of courtesy (burima al-adab) that amounts to ignorance of God-given, illuminated knowledge (al-jahl bi al-ilm al-ladunni al-fathi) as much as itindicates loss of insight (lam yakun 'alabasirah min amribi) ('Arabi, n.d., 2: 645,233$)$. That is why the literal sense of the text must always be honoured. However, if, after that, God opens up one's understanding to perceive other meanings which preserve the literal sense while adding new 
knowledge, one may accept that new understanding and thank God. One cannot, nevertheless, interpret the text on the basis of common sense or scientific fact or any other product of reason. One should not venture into the text without preparation. That is to say, unless and until one has fulfilled the Shari'ah requirements upon himself and sought understanding from God through faith constant (iman), practice ('amal), and God-fearing (taqwa), ('Arabi, n.d., 2: 531) one cannot have a justifiable basis upon which to understand the revealed text.

Indeed, those preconditions for understanding preclude the possibility of a novel or innovative interpretation. The required piety, God-fearing, strict adherence to Shari'ah and the Sunnah, as well as deep respect for those who have gone before in the way of the Prophet (warathat al-anbiya), and the acknowledgement of one's own nothingness in the face the omniscient God, all work against any attempts at innovation (bid'ab). A "new" interpretation must therefore first take into account those which the early scholars have suggested and not contradict them. If it adds another dimension to the accepted tradition and harmonizes it with previous interpretations, while the interpreter possesses all the requisite personal qualities cited above, then it might be valid and justified. Otherwise, it deserves neither attention nor acceptance ('Arabi, n.d., 2: 233-234).

It must be further noted that for Ibn 'Arabi, the Quranic context is the divine knowledge from which nothing is hidden. Once we understand that the text is God's own speech, historical considerations are of no account, even though we affirm that the Quran can throw light on a number of phenomena connected to the historical situation at the time of the Prophet. To anyone who would criticize his approach to the Quranic text, Ibn 'Arabi's basic answer, as we shall see, is that any interpretation supported by the literal text is valid. To put it in other words, we shall not object to an interpretation proposed by a scholar ('alim), so long as the literal text lends it support, though we may consider it to be bound 
and constrained by the person's limited perspective. To say that a certain scholar's interpretation is wrong is to affirm that God could not have meant that in that verse -aconclusion reached through rational faculty that would tie God down to our own idea of what He is. In Ibn 'Arabi's view, since the Quran is God's Speech and His knowledge embraces all things, God knows every possible meaning that can be understood from His Speech. One may also say that God intends every one of those meanings, though not necessarily for everybody. In Ibn 'Arabi's words :

Every sense (wajh), which is supported by (tabtamilubu) any verse in God's Speech -beit the Quran or other scripturesin the view of anyone who knows that language, is intended (maqsud) by God in the case of that particular interpreter (muta'awnil). For, His knowledge encompasses all senses ... Therefore, every interpreter correctly grasps (musib) the intention of God in that word ... and so we have no reason to declare wrong a scholar's interpretation supported by the word (la sabila ila takbti'at 'alim fi ta'wil yabtamilubu al-laf:). He who does so is extremely lacking in knowledge. But that interpretation does not bind everyone. Only the interpreter himself and those who follow his authority may hold and put it into practice ('Arabi, n.d., 2: 119).

He who sent it [i.e. the Revealed text] down knows all those possible meanings (munazzilaha 'alim bi-tilka al-wujub kulliha) as He knows that His servants are of different levels in looking into the word and that He only expects them to do what they can understand from His speech. Thus, when someone understands a sense from the verse, that meaning is intended by God in this verse in the case of the person who finds it....Therefore, everyone who comments on the Quran and does not go beyond what the word implies (lam yakhruj 'amma yahtamilubu al-laf $\approx$ ) is a true exegete (mufassir). But "he who makes commentary based on his own opinion" becomes an unbeliever (faqad kafara), unless the speakers of the [Arabic] language recognize that sense in that word." ('Arabi, n.d., 2: 567). 
Now, given the polysemy of Arabic vocabularies, rigorous commitment to the words of the revelation does not exclude but, on the contrary, it implies a multiplicity of interpretations. But this conclusion should in no way be understood as an invitation to engage in erudite philological exercises during recitation, even though the divinely inspired understanding is in perpetual renewal (tajdid khalqi fahm) and thus allows the discovery of unprecedented meanings each time one is reciting the Quran. This is because, according to Ibn 'Arabi, the descent (nu₹ul) of the Quran will never cease as long as it is recited (Chodkiewics 1992: 25) and that the incessantly revealed Quran continually brings new meanings to the hearts prepared to receive it:

You should distinguish between understanding the speech (kalam) and understanding Him who is speaking. It is the second comprehension that must be sought, which can be obtained only by him upon whose heart the Quran descends; while the first belongs to the common people. Those who seek to understand the speaker will understand His speech, whereas those who understand only the word might not be able to grasp what the speaker exactly means (ma arada bib 'ala al-ta'yin).... The descent of the Quran upon the heart with a special understanding represents God's recitation onto the servant and vice versa... so that the servant whose illuminated inner sight is guided "by a light from his Lord" (39:22) obtains with each recitation of a verse a new understanding distinct from that which he previously had during the preceding recitation and that which he will obtain during the subsequent one, for God has answered the request that he addressed, "Oh Lord, increase me in knowledge! (rabbi zidni 'ilma)" (20:114) ('Arabi, n.d., 3: 128-129). 


\section{Allusive Exegesis}

Since Ibn 'Arabi often uses the word ta'wil in the negative sense it is, therefore, not an appropriate term to describe Ibn 'Arabi'sinterpretive method. This is because his approach to the Quran consists not so much in interpreting the text allegorically as it is a commentary by allusions (tafsir bi al-isharah). If the jurists (fuqaha), particulary the Hanafites, have relied on the fourfold division of the meanings of the text into significative ('ibarah), implicative (isharah), analogical (dalalah), and assumptive (iqtida) as the basis for interpreting the Quran from a legal viewpoint, (Al-Nasafi 1986, 1:374-405); (Salih 1993, 1: 469-590); (Zahrah 1928: 110-116) the Sufis' whole approach is best represented and couched in the term isharat ('allusion'). Arabic lexicons tell us that the verb ashara, from which its noun derives, literally means to point to or to give a sign as, for instance, to nod the head or point one's finger (Manurr, n.d., 4: 428-429); (Lane 1984, 2: 1616). The story of Mary and her baby is a case in point; when she brought the infant Jesus to her folk, they said, "Mary, thou hast surely committed a monstrous thing!" ... [she kept silent] and "pointed to" him (the baby), i.e., she made an allusion which he understood and then he spoke in her defense. ${ }^{4}$ It must be noted that every act of allusion involves at least four elements: [1] the one who makes allusion (al-mushir), [2] the one to whom the allusion is addressed (al-mushar [labu]), [3] that by which allusion is made (al-mushar bib) and [4] that to which one alludes (al mushar ilayh) or that which is intended (al-maqsud) or meant (al-ma'na). ${ }^{5}$

Ibn 'Arabi uses the word isharat as a technical term by which he refers to the Sufi commentaries of the Quran. "Just as Mary turn to allusion, so did our companions have turned to allusions; [that is to say] their speech while explaining His Book is called isharat although it contains truth (baqiqab) and constitutes exposition of its meanings (tafsir li ma'anib)." ('Arabi, n.d.,

4 See al-Qur'an, 19: 27-33.

5 I have in mind Ibn Sina's notion of ma'na, which gave rise to the medieval and modern Western philosophical theories of intentio, intentionality, and meaning. 
1: 279). By "our companions" Ibn "Arabi might have in mind the Sufi authors and their Quran commentaries such as Tafsir al-Quran al-Azim of Sahl al-Tustari (d. 896), (Al-Tustari 1911); (Bowering 1980) the Haqa'iq al-Tafsir of al-Sulami (d. 1021), (Al-Sulami 1995) and the Lata'if al-Isharat of al-Qushayri (d. 1073) (Basyunu 1981). Modern scholars assert that the credit for this unique method of exegesis goes to Ja ${ }^{6}$ far al-Sadiq (d. 765), a celebrated scholar who reportedly discerned four levels of meaning in the Quran: (1) the obvious, literal meaning (ibarah) which is addressed to the mass of believers, (2- the allusion (isharah) which is perceptible to the spiritual elect among the believers, (3) the subtle meanings (lata'if) which is lying beyond the allusions and meant for the elect of the elect, and (4] the truths (haqa'iq) which are comprehensible only to the prophets. (Nwyja 1968: 181); (Nwyja 1970); (Zahra 2006).

Nonetheless, medieval scholars such as al-Mawardi (d. 1058) and al-Suyuti (d. 1505) pointed out that this exegetical method originated from Ibn 'Abbas, who had reportedly said: "Commentary falls into four categories (wujub): (1) that which the Arabs understand in their tongue, (2) that which everybody should not be ignorant about, (3) that which the scholars have set forth, and (4) that which only God knows." four categoriesof tafsir, al-Mawardi goes on to explain, may be understood as referring to the linguistic (baqa'iq al-lughah), the legal (shara'i), the allegorical (mutashabihat), and the metaphorical or symbolic (al-ghayb wa al-sam'iyyat) types of explanation. (Al-Mawardi 1992, 1: 36-40). There is another tradition attributed to 'Ala ibn Aba Talib (d. 661) and 'Abd Allah ibn Mas'ud (d. 652) which says that "each revealed verse of the Quran has an exterior meaning (dzabr) and an inner sense (batn); and each letter/ word (barf) has a limit (badd) and for every limit there is a starting-point (matla)."?

6 Reported by Ibn Jarir al-Tabari (d. 923) in his tafsir, 1:76. Its authenticity, howecer, is questioned by Ibn Kathir (d. 1373) and al-Suyuti because of a certain transmitter called Muhammad b. al-Sa'ib al-Kalbi.

7 Reported by: Ibn Hibban in his Sabịh (hadīth no. 74); al-Haythamī in his Majma' al-Zawa'id, 7: 152 on the authority of al-Bazzar, AbūYa'la and al-Ṭabranī; 
According to al-Tustari, the obvious meaning is the recitation (tilawah), the hidden sense is the understanding $(f a b m)$, whereas the limit defines the lawful and the unlawful (balal andharam), and the starting-point is the spiritual approach to the intended meaning through God-given understanding (ishraf al-qalb 'ala al-murad biha fiqhan min Allah) (Tustari, n.d.: 139). But identical classification of scriptural senses is also found in the writings of al-Muhasibi (d. 857) who, as many Orientalists suspect, might have learned it from some Jewish or Christian sources, in view of its close resemblance with the quadrivium of medieval Biblical hermeneutics, namely, the literal (bistoria), symbolic (allegoria), prescriptive (tropologia), and spiritual (anagoge) (Ess 1961: 210-211); (Freedman 1992, 1: 435-436) as well as with that of Talmudic exegesis, i.e., narrative (haggadic), legal (balakhic), textual (masoteric), rhetorical and allegorical (Wansbrough 1977). Whatever the case may be, all these traditions have become a kind of overtures for the subsequent development of various techniques of tafsir and provided a solid ground for ta'wil.

In Ibn 'Arabi's interpretive scheme, God's saying in the Quran: "We shall show them our signs (ayat) on the horizons and in themselves" (41:53) constitutes the point of departure. Speaking on behalf of God's Folk (Abl Allab), Ibn 'Arabi asserts that every revealed verse has two senses (wajhani); a sense which they see outside of themselves and a sense which they see see within themselves ('Arabi, n.d., 2: 567). The latter is called "allusions" which they used in their discourse in order to defend themselves against the vile accusation of unbelief by the exoteric scholars ('ulama' al-rusum) ('Arabi, n.d., 1: 279). In Ibn 'Arabi's view, the Folk of God are more deserving of explaining the revelation because they are the inheritors of the prophets who are directly taught by God. In other words, it is God who has sent down understanding upon their hearts so that, like al-Ṭabarī in his tafsìr, I: 22; and by al-Baghawī in his Sharḅ al-SunnabI: 262 on the authority of al-Hasan al-Bașrī. A critical comment by Ibn Hajar al-'Asqalanī (d. 1449) on this tradition is given in Tubfat al-Ahwadhi, 8:280. 
prophets, they will never say anything about God which He has not said ('Arabi, n.d., 1: 280). Thus, they derive their sayings neither from their own souls nor from their rational faculty. They do not speak according to conjecture or surmise (ghalabat al-zann) but, instead, their discourse is founded "upon insight" ('ala basirah) and "a clear evidence from God" ('ala bayyinah min rabbih) ('Arabi, n.d., 1: 279). To support his assertion Ibn 'Arabi cites the following Quranic verses: "Recite in the name of thy Lord ... who taught man what they knew not" (96:1-5); "He created man, He taught him the explanation" (55:3-4); "He has taught you what you know not" (4:113); "He gives wisdom to whomsoever He will" (2:269). All this is not impossible since God commanded Moses to learn from one of His servants "whom We have given mercy from Ourselves and whom We have taught knowledge from Our own Presence" (18:65); and God says: "We are closer to him than his jugular vein" (50:16) ('Arabi, n.d., 1: 279).

According to Ibn 'Arabi, the People of God (Ablullah) have employed the term isharah ('allusion') rather than other terms for their commentaries of God's Book partly because they follow the example of the Prophet who used to derive a good omen by way of allusion, and partly because of a divine teaching which the exoteric scholars have no knowledge about ('Arabi, n.d., 1: 281). To sum up, isharah is a technical term (istilab) unknown to others unless one learned from those who set it down, and is used only in their writings and compositions or when an outsider is present with them in the same way the Arabs employ analogies and metaphors in their speech so that the stranger who sits with them will not know what they are doing or saying ('Arabi, n.d., 1: 281). Allusion can be given in various forms including verbal and non-verbal signs, letters, symbols, etc.

Let us examine how Ibn 'Arabi employs allusion in his interpretation of Quranic verses without ever losing his concern for literal sense, such that he never look for what is outside of the letter elsewhere than within 
the word itself. Following are a few instances from Ibn 'Arabi's works that would best illustrate his method as shown in his commentary on the opening chapter of the Quran (surat al-Fatihah) and other randomly selected verses. Ibn 'Arabi begins with the exposition of the secrets of basmalah, the first verse of the opening chapter, by saying that the letter "ب" (ba) in the phrase bismi (بسم) symbolizes the coming of things into existence, whereas the dot (nuqtah) that is placed under it serves to distinguish between the worshipper and the one who is worshipped (al-abid wa-l ma'bud). Morever, the letter $b a$ ' is also a substitute for the conjunctive letter (bamzat al-wash) of the word ism (اسم) which is not vocalized and simply omitted because, according to Ibn 'Arabi, the absence of vowel (sukun) signifies nothingness or non-existence ('adam), whereas the appearance of vowel (barakah) designates the act of bringing things into existence (ijad). This is why the $b a^{\prime}$ 'is vocalized with kasrab; just as God has brought things into existence and subjected them to His command, so does this letter $b a^{\prime}$ have brought change in the vowel of letter mim in the word ism through a subdual (khafd) -as if God says, "With me stands every existent thing (bi qama kullu manjudin)." The letter "s" (w) of the word ism, as we notice, is likewise deprived of any vowel (sakin) in order to indicate obedience and submission of the creature to their Creator ('Arabi, n.d., 1: 102-103).

Ibn 'Arabi proceeds to unpack in lengthy detail the secrets and meanings of God's name Allab which, he maintains, consists of six letters: alif, lam, lam, alif, ha; and waw. Given the time and space constraint here, we shall present only some of his remarks on this Divine Name known as Lafz al-Jalalah ('Expression of Majesty'). There are two alifs in the name, one belonging to the letter hamzah, another to lam. But why does the first alif stand alone, while the second is attached to another letter? According to Ibn 'Arabi, this is because the first alif denotes the Originator "who had existed whilenothing elseexisted along with Him (kana Allah wa la shay'a $\left.m a^{\prime} a b u\right)$ " in the beginning, whereas the second alifis attached to the lam of 
existent (manjud) so as to signify God's making known Himself through His creating things and bringing them from nothingness into existence. Without this second alif, none of the lams which follow could ever be pronounced -anallusion that unless God lent them His wujud, no creature would ever come into existence at all.

Now, the first of the two lams (J) that we find in the divine name is called thelam al-manjud (the "L" of being) and the second lam al-malakut (the "L" of dominion), both representing God's absolute power over all creatures. These two lams are also deprived of vowel because they occur between the "A" of primacy (alif al-awwaliyyah) and the " $\mathrm{A}$ " (I) of unity (alif al-wahdaniyyah), just as all creatures are bound to vanish and return to the state of non-existence when the creator remains. Next comes the letter $b a^{\prime}(\bullet)$ which is not only separated from the preceding letters but also singled out by the waw (9) of "He-ness" (buwiyyah) so that, like the first alif, it stands alone and remains detached (maqtu'ab) from anything. This, Ibn 'Arabi tells us, is in conformity with God's saying that "He is the First and the Last (Huwa al-Awwalwa al-Akbir)." ('Arabi, n.d., 1: 105).

Moreover, we are told that the phrase bismi-llabi-rrabmani-rrabim comprises four words (alfas) and four meanings, amounting to 'eight' which is the number of the Throne Carriers (bamalat al-'arsh). ${ }^{9}$ According to Ibn 'Arabi, the basmalab has no less than one thousand meanings, of which none will not manifest itself until a year (hawl) is complete. Ibn 'Arabi is referring here to a saying of the Prophet, "If my followers (ummati) are alright (salahat) they will have a full day but if they go wrong (fasadat) they will have half a day" -having in mind the Divine Day (yawm rabbani) which is equivalent with a thousand years of our reckoning. ${ }^{10}$ On the basis of this

8 Al-Qur'an, 57:3.

9 Refering to the Qur'an, 69:17.

10 See the Qur'an, 32:5. Ibn 'Arabī distinguishes three Divine days; that of Lord (ayyam al-rabb), that of Allah (ayyam Allab), and that of the One who possesses the ways of ascent (ayyamdhi-l ma'arij).

DINIKA, Volume 4, Number 2, May - August 2019 
hadith, Ibn 'Arabi holds that the meaning of the basmalah always manifests at least once in a millennium (a day in divine reckoning), and this explains why Muslims are blessed with the Divine Sciences ('ulum ilabiyyah) more than any other community ('Arabi, n.d., 1: 109).

Coming next to the body of the surah, Ibn 'Arabi first reminds us of the other names by which it is also known, i.e., the Mother of the Book (Umm al-Kitab), the Mother of the Quran (Umm al-Quran), the Opener of the Book (Fatihat al-Kitab), the Seven Pairs (al-Sab'al-Mathani). According to Ibn 'Arabi, it is called "the Mother" because it brings together everything as it is encompassing all the scriptures revealed to previous prophets including the Injil ('Gospel') of Prophet 'Isa, the Tawrah ('Torah') of Prophet Musa, the Zabur ('Psalms') of Prophet Dawud, and the so-called Subuf ('Leafs') of Prophet Ibrahim -peace be upon each of them. This is the meaning of Prophet Muhammad's statement, "I was given all-comprehensive words (utitu jawami" al-kalim)" and "Were Moses alive, he would find it impossible not to follow me (law kana Musa hayyan, lama wasi'ahu alla yattabi 'ani)" because Prophet Muhammad's law comprises all previous laws (shara'i') ('Arabi, n.d., 1: 111, 2: 134).

But al-Fatihah is not only "the one which opens up" varieties of Divine theophany (tajalliyat) but it is also "the one which suffices" (alKafyah). It is called "the seven pairs" for in it are embodied the meanings of Lordship and servitude at the same time ('Arabi 1961: 95); (Chodkiewics 1992: 111). Citing the divine saying (hadith qudsi) from the Prophet that God has divided prayer [i.e. al-Fatihah] into two parts, a part for Himself and the other for His servant, Ibn 'Arabi concludes that al-Fatihah has two sides and a middle, or two parts and a link between them. God's part are the first four verses, while the intermediary is verse number five, and the last three belong to man's part. The intermediate verse puts God's part (iyyaka na'bud) and man's part (iyyaka nasta'in) in a single sentence such that, Ibn 'Arabi explains: 
... all that remain are but two presences (hadratani) that give it the eponym al-mathani ("the two at once"), namely that which brings manifest the existence in the True-Real (al-Haqq) and that which actualizes the creation (ijad) in the servant. [In sum,] it is [where] His isolation from you (ifradubu 'anka) and your meeting with Him (jam'uka bibi) takes place ('Arabi, n.d., 1: 111).

\section{Conclusion}

It is impossible to make a thorough analysis of Ibn 'Arabi's treatment of the Quran as a whole in order to assess the scope and character of his interpretive method, and there is certainly no guarantee that a random sample of the treatment of particular verses or passages will produce results true for his hermeneutics as a whole. It is clear however that Ibn 'Arabi's approach to Quranic interpretation rests on the assumption that all the possible meanings of any given word or group of words in the Quran are considered valid so long as the Arabic language allows it and, therefore, rejection of any one of these meanings would imply limiting God's infinite knowledge and inappropriately saying that God was unaware of the various ways in which His word could be interpreted.

There is no doubt that Ibn 'Arabi rebukes rational interpretation (ta'wil 'aqli) outright, declaring that any ambiguous verse (al-ayat almutashabihat) of the Quran that reason may find hard to swallow only proves its own imperfection and its failure to comprehend rather than affirms the necessity of interpretation. While he insists that one's reading of the Quran must conform to the Arabic language as spoken by its original recipient, Ibn 'Arabi does offer surprising and highly original interpretations which try to uncover the mystical treasures hidden in the text. But rather than impose his own ideas on the sacred text, more often than not Ibn 'Arabi tried to discover ideas in the course of his experiential dialogue with the text. 
As we have seen, Ibn 'Arabi's method of interpreting the ambiguous verses is no less traditional than the widely accepted method of tafsir. In other words, he does not violate the established canons of interpretation since he maintains that nobody is allowed to explicate the meaning of the Quran with one's own, personal opinion (bi-l ra'yl). That is to say, unless an interpretation is supported by other relevant verses of the Quran or by the prophetic tradition and based upon a thorough mastery of Arabic as well as a good knowledge of hadith andother traditional Islamic sciences, it must be rejected and condemned. Hence, only that which falls short of these criteria and contradicts the Shari'ah and the apparent meaning of the verse is called the tafsir bi-l ra'yi. One must first meet the general requirements in order to qualify as a mufassir in the technical sense of the word. In conclusion we may assert that it is incorrect to describe Ibn 'Arabi's exegesis as a kind of esoteric interpretation (tafsir batini). Although it lies out of the category of tafsir bi-l ra'y, Ibn 'Arabi's approach does belong to what is called "interpretation by allusion" (tafsir bi al isharat) which, in the final analysis, turns out to benothing but a profound meditation (tadabbur) on the Holy Quran that is grounded neither on reason ('aql) nor on whim (hawa). Wallabu a lam.

\section{References}

'Arabi, Ibn. n.d. Al-Futuhat al-Makkiyyah. Beirut: Dar Sadir. . 1961. Tanazzulat Mansaliyyah. Cairo.

Addas, Claude. 1989. Ibn 'Arabiou La Quete Du Soufre Ronge. Paris: Gallimard. 1993. Quest for the Red Sulphur: The Life of Ibn 'Arabi. Cambridge: Islamic Text Society.

Al-Alusi. 1985. Ruh al-Ma'Ani. Beirut: Dar Ihya al-Turath al-'Arabi.

Al-Dhahabi. 2001. Siyar A Lam al-Nubala.' Damaskus: Mu'assasat al- 
Risalah.

Al-Dhahabi, Muhammad Husayn. 1961. Al-Tafsir Wa al-Mufassirun. 2 Vols. Cairo: Dar al-Kutub al-Hadithah.

Al-Ghazali. 1962. Al-Iqtisadfi al-I Tiqad. Ankara: Nur Matbaasi.

Al-Ghubrini. 1979. 'Unwanal-Dirayahfiman 'Urifaminal- 'Ulama'Fì al-Mi'AtalSabi'abbi-Bijayah. Beirut: Dar Afaq al-Jadidah.

Al-Maturidi. 1983. Ta'wilat Abl al-Sunnah. Edited by M.M. Al-Rahman. Baghdad: Maktabah al-Irshad.

Al-Mawardi. 1992. al-Nukatwa al-'Uyun. Beirut: Dar al-Kutub al-'Ilmiyyah.

Al-Najjar, Muhammad 'Abd al-Halim, ed. 1965. Madhahib al-Tafsir alIslamiyy (Terj). Cairo: Matba'at al-Khanji.

Al-Nasafi, Hafi al-Din. 1986. Kashf al-Asrar Fi Sharh al-Manar. Mecca: Dar al-Baz.

Al-Sha'rani, 'Abd al-Wahhab. 1888. Lawaqih al-Anwar Fi Tabaqat al-Akhyar. Istanbul.

Al-Sulami. 1995. "Ziyadat Haqa'iq al-Tafsir." In The Minor Quran Commentary of Abu Abdar-Rahman Muhammad b. al-Husayn asSulami (d. 412/1021), edited by Gerhard Bowering. Beirut: Dar alMachreq.

Al-Suyuti. 1978. Al-Itqanfi 'ulum al-Quran. Cairo: Mustafa al-Bab al-Halabi.

Al-Tustari, Sahl. 1911. Tafsir al-Quran al-Az̨im. Cairo: Dar al-Kutub alGharbiyyah al-Kubra.

Al-Yafi'i. 1970. Mir'at al-Jinan Wa 'Tbrat al-Yaqzan. Beirut: Mu'assasat alA'lami.

Al-Zarkashi. 1957. Al-Burhanfi 'ulum al-Quran. Cairo: Isa al-bab al-Halabi.

Basyunu, Ibrahim. 1981. No Title. 2nd ed. Cairo.

Bowering, Gerhard. 1980. The Mystical Vision of Existence in Classical Islam: The Quranic Hermeneutics of the SufiSabl al-Tustari (d.283/896). Berlin and New Yok: Walter de Gruvter.

Chittick, William C. 1989. Ibn al-Arabi's Metaphysics of Imagination: The Sufi Path of Knowledge. Albany: State University Of New York Press. 
Chodkiewics, Michel. 1992. Un Ocean Sans Rivage Ibn 'Arabi, Le Livre et Le Loi. Seuil: Librairie du XX siecle.

. 1999. "Le Proces Posthume d'Ibn 'Arabi." In Islamic Mysticism Contested: Thirteen Centuries of Controversies and Polemics, edited by Frederick de Jong and Bernd Radtke, 93-123. Leiden: Brill.

Corbin, Henri. 1969. Creative Imagination in the Sufism of Ibn 'Arabi. Priceton: Princeton University Press.

Corbin, Henry. 1969. Creative Imagination in the Sufism of Ibn 'Arabi. New Jersey: Princenton University Press.

Elmore, Gerald. 2004. "Some Recent Editions of Books by Ibn 'Arabi Published in the Arab World." Arabica 51 (3).

Ess, J. Van. 1961. Die Gedankenwelt Des Hari al-Muhasibi. Bonn: Universitas Verlag.

Freedman, David Noel, ed. 1992. The Anchor Bible Dictionary. New York: Doubleday.

Goldziher, Ignacz. 1970. Die Richtungen Der Islamischen Koranauslegung. Leiden: Brill.

Knysh, Alexander. 1999a. Ibn 'Arabi in the Later Islamic Tradition: The Making of a Polemical Image in Medieval Islam. Albany, New York: State University of New York Press. . 1999b. Ibn 'A rabi in the Later Islamic Tradition. Albany: SUNY Press.

Lane, Edward. 1984. Arabic-English Lexicon. Cambridge: Islamic Text Society.

Manurr, Ibn. n.d. Lisan al-'Arab. Beirut: Dar Sadir.

Nasr, Seyyed Hossein. 1975. Three Sufi Sages: Avicenna, Subrawardi, Ibn Arabi. Cambridge: Cambridge University Press.

Nwyja, Paul. 1968. "Le Tafsir Mystique Attribue a Ga'far Sadiq." In Melanges de l'Universite Saint-Joseph 43. . 1970. Exegese Coranique et Langage Mystique. Beirut: Dar al-Machreq.

Salih, Muhammad Adib. 1993. Tafsir al-Nusus. 4th ed. Beirut: Al-Maktab al-Islami.

Streight, David, ed. 1993. An Ocean without Shore (Terj). Albany: State University Of New York Press. 
Tustari. n.d. "Tafsīr.” In Mystical Vision, edited by Gerhard Bowering, 3rd ed.

Wansbrough, John. 1977. Quranic Studies: Sources and Method of Quranic Interpretation. Oxford: University Press.

Yahla, Osman. 1964. Histoire Et Classificationde L 'Oeuvre D'Ibn 'Arabi: Etude Critique. Damaskus: Institut Francais de Damas.

Zahra, Kristin. 2006. Sufi Commentaries on the Quran in Classical Islam. Abingdon: Routledge.

Zahrah, Muhammad Abu. 1928. Usul al-Fiqh. Cairo: Dar al-Fikr al-'Arabi.

Zayd, Nasr Hamid Abu. 1983. Falsafat al-Ta'wil: Dirasahfi Ta'wil al-Quran inda Ibn 'Arabi. Beirut: Dar al-Tanwir. 